\title{
(Arte)
}

\section{Pinocho de Toledo}

\author{
Por Héctor García Valerio \\ Estudiante del VIII semestre \\ de la Licenciatura en Artes Plásticas \\ hector.valerio@hotmail.com
}

Imaginar que una marioneta cobre vida es algo absurdo, descabellado y hasta terrorífico, pero para el escritor y periodista Carlo Collodi no, ya que escribió un cuento en el que narra como una marioneta de madera cobra vida para después de muchas aventuras desafortunadas, un ser mágico, le concediera la dicha de ser un niño de verdad.

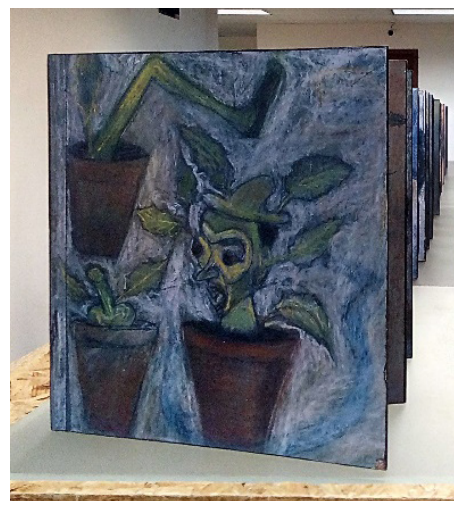

Francisco Toledo realiza una re-interpretación plástica del cuento de Pinocho, la cual se muestra en la exposición inaugurada el 15 de febrero del 2018, en los pasillos de La licenciatura en Artes Escénicas de la Universidad de Sonora. Se trata de una réplica exacta de la obra de Toledo realizada en la ciudad de México, la cual está en posesión del Instituto Municipal de Cultura y Arte (IMCA).

La exposición lleva por nombre Pinocho. Está compuesta por 54 piezas conteniendo imágenes por ambos lados de los lienzos, razón por la cual se montó en forma de acordeón facilitando la lectura. Las piezas originales están realizadas con la técnica del pastel y los papeles utilizados como soportes fueron elaborados con materiales reciclados. En la inauguración estuvo a cargo de Rodolfo Nevárez Medina, Subdirector de Vinculación Cultural del IMCA, a nombre de Margarita Torres Ibarra, titular de la dependencia y Adria Adelina Peña Flores Jefa del Departamento de Bellas Artes la cual comentó que, "llevar esta obra a los pasillos de la Licenciatura en Artes Escénicas tiene la finalidad de servir de herramienta inspiradora para los alumnos de la academia".

En la inauguración estuvieron presentes alumnos/as de la Licenciatura de artes plásticas, así como de Artes Escénicas los cuales dieron el recorrido a la obra observando este singular formato, el cual se montó sobre una mesa larga. Esta réplica de la obra de Toledo es itinerante razón por la cual estará temporalmente en los pasillos del Departamento, para después ser trasladada a otro recinto o dependencia. 